\title{
KOMUNIKASI PERSUASIF TERHADAP IMPLEMENTASI PERATURAN DAERAH NOMOR 16 TAHUN 2012 DI KOTA BANJARMASIN (STUDI KASUS PENCEGAHAN NARKOBA OLEH BADAN NARKOTIKA NASIONAL)
}

\author{
Bachruddin Ali Akhmad ${ }^{1)}$, Mahyuni ${ }^{2)}$,Benny Wahyudi ${ }^{3)}$ \\ Universitas Lambung Mangkurat Banjarmasin \\ Email: benswahyu90@gmail.com
}

\begin{abstract}
ABSTRAK
Komunikasi secara persuasif sangat penting dalam meningkatkan kualitas pemerintahan dalam sosialisasi serta mengembangkan informasi tentang peraturan daerah dan kebijakan. Tujuan penelitian ini untuk mengetahui Implementasi Peraturan Daerah Nomor 16 Tahun 2012 Tentang Pencegahan Dan Penanggulangan Terhadap Penyalahgunaan Dan Peredaran Gelap Narkotika, Psikotropika Dan Zat Adiktif Lainnya (P4GN) di Kota Banjarmasin (Studi Kasus Pencegahan Narkoba Oleh Badan Narkotika Nasional). Metode penelitian dengan pendekatan kualitatif dan tipe deskriptif. Instrumen penelitiannya adalah peneliti itu sendiri. Teknik pengumpulan data dalam penelitian ini yaitu observasi, wawancara dan dokumentasi. Analisis data yang digunakan yaitu reduksi data, penyajian data dan verifikasi. Keabsahan data yang digunakan dengan teknik uji kredabilitas. Hasil penelitian menunjukkan bahwa Implementasi Peraturan Daerah Nomor 16 Tahun 2012 Tentang Pencegahan dan Penanggulangan Terhadap Penyalahgunaan dan Peredaran Gelap Narkotika, Psikotropika dan Zat Adiktif Lainnya (P4GN) di Kota Banjarmasin (Studi Kasus Pencegahan Narkoba Oleh Badan Narkotika Nasional) belum berhasil dilaksanakan secara maksimal. Karena diantara keempat faktor implementasi menurut teori Edward III hanya satu faktor yang berhasil dijalankan secara maksimal, yaitu faktor sumberdaya. Sedangkan faktor komunikasi, disposisi dan struktur birokrasi belum berhasil dilaksanakan. Karena indikator terdapat dalam setiap faktor masih ada yang belum dilaksanakan maksimal. Seperti dalam faktor komunikasi hanya indikator konsistensi yang berhasil dilaksanakan. Pada faktor disposisi terdapat indikator staff yang belum dilaksanakan dan pada faktor struktur birokrasi kedua indikatornya belum berhasil dilaksanakan. Disarankan kepada BNN Kota Banjarmasin agar lebih sering mengadakan sosialisasi kepada masyarakat mengenai P4GN. Termasuk dasar hukumnya dan isi dasar hukum. Sedangkan kepada masyarakat agar dapat membantu BNN dalam mengatasi masalah penyalahgunaan dan peredaran narkoba.
\end{abstract}

Kata kunci: Implementasi Kebijakan;Penyalahgunaan dan Peredaran Gelap Narkotika, Psikotropika dan Zat Adiktif Lainnya.

\section{PENDAHULUAN}

Sosialisasi merupakan cara yang cukup efektif dalam mensukseskan program jangka pendek maupun jangka panjang, untuk itulah komunikasi yang baik diperlukan untuk menciptakan kesepahaman antara Badan Narkotika Nasional (BNN) dengan masyarakat. Narkoba merupakan salah satu permasalahan sosial yang terus mengalami peningkatan penggunanya. Bahkan pada saat ini Indonesia dapat dikatakan berstatus darurat narkoba. Melalui data yang dimiliki Badan narkotika Nasional jumlah peredaran narkoba yang ada di Indonesia semakin harinya semakin meningkat. Pada tahun 2016, pengguna narkoba di Indonesia mencapai 5,9 juta orang. Bahkan melalui hasil penelitian didunia terdapat kurang lebih satu juta orang di dunia menggunakan narkoba pada jenis crystalline methamphetamine dan banyak penggunanya adalah pelajar". 1

Merespon perkembangan permasalahan narkotika yang terus meningkat dan makin serius, maka Ketetapan MPR-RI Nomor VI/MPR/2002 melalui Sidang Umum Majelis Permusyawaratan Rakyat Republik Indonesia (MPR-RI) Tahun 2002 telah merekomendasikan kepada DPR-RI dan Presiden RI untuk melakukan perubahan atas Undang-Undang Nomor 22 Tahun 1997 tentang Narkotika. Oleh karena itu, Pemerintahan dan DPR-RI mengesahkan dan mengundangkan Undang-Undang Nomor 35 Tahun 2009 tentang Narkotika, sebagai perubahan atas UU Nomor 1997. Selain itu pemerintah juga melaksanakan kebijakan lainnya dengan mengeluarkan Instruksi Presiden Nomor 12 Tahun 2011 Tentang

\footnotetext{
${ }^{1}$ Tribunnews,Rabu29Maret2017
} 
Pelaksanaan Kebijakan dan Strategi Nasional Pencegahan dan Pemberantasan Penyalahgunaan dan Peredaran gelap Narkoba (P4GN). Tujuan kebijakan tersebut untuk mewujudkan Indonesia yang bebas dari narkoba. Berdasarkan UU No.35 Tahun 2009 tadi, maka untuk menjalankan kebijakan P4GN tersebut maka pemerintah juga membentuk Badan Narkotika Nasional.

Di Pulau Kalimantan terdapat beberapa Provinsi. Salah satunya adalah Kalimantan Selatan. Di Provinsi Kalimantan Selatan prevalensi penyalahguna narkotika usia populasi 10-59 Tahun $\geq 55,598$ Jiwa (1,98\%). Dimana penggunanya tidak hanya kalangan dewasa saja tetapi juga remaja. Remaja yang mengunakan narkoba sebanyak $27 \%$ di Kalimantan Selatan. ${ }^{2}$

Salah satu Kota/Kabupaten yang sangat banyak menggunakan penyalahgunaan narkoba adalah Kota Banjarmasin. Menurut Badan Narkotika Nasional Kota Banjarmasin terdapat 12.000 orang yang aktif menggunakan narkotika di Kota Banjarmasin. Hal tersebut membuat Kota Banjarmasin sebagai kota paling banyak pecandu narkoba sekalimantan Selatan. Maka Badan Narkotika Nasional (BNN) Kota Banjarmasin juga ikut serta dalam mengimplementasikan kebijakan P4GN. Salah satu cara mengatasi permasalahan narkoba tersebut yaitu dengan cara menjalankan kebijakan pencegahan, pemberantasan, penyalahgunaan dan peredaran gelap narkoba.

Di Kalimantan Selatan kebijakan ini tertuang dalam Peraturan daerah Kalimantan Selatan Nomor 16 Tahun 2012 Tentang Pencegahan dan Penanggulangan Terhadap Penyalahgunaan dan Peredaran Gelap Narkotika, Psikotropika dan Zat Adiktif Lainnya. Perda ini merupakan perda Kalimantan Selatan yang mengatur semua berkaitan dengan penyalahgunaan narkoba (P4GN). Peraturan daerah tersebut dijadikan sebagai bahan acuan atau rujukan untuk mengatur pelanggaran narkoba di semua Kota dan Kabupaten yang ada di Kalimantan Selatan, termasuk di Kota Banjarmasin.

Tetapi pada dasarnya Peraturan Daerah Kalimantan Selatan Nomor 16 Tahun 2012 tersebut tidak cukup untuk menjalankan kebijakan P4GN yang ada di Kota Banjarmasin. Hal ini disebabkan karena perda tersebut merupakan perda Kalimantan Selatan dan bukan perda Kota Banjarmasin berisi P4GN. Selain itu apabila perda tersebut hanya dibuat dan tetapi tidak diterapkan dan disosialisasikan maka juga tidak akan menguranggi penggunaan narkotika yang ada di

2 Banjarmasinpost.co.id, Rabu12Maret2019.
Kota Banjarmasin dan membuat penggunanya semakin meningkat.

Seperti diungkapkan Kepala BNN Kota Banjarmasin H. Ilyas, 2017 yang mengatakan "bahwa sebaiknya pemerintah Kota Banjarmasin segera membuat Peraturan Daerah tentang penyalahgunaan obat terlarang yang termasuk pada daftar obat-obatan jenis $G$ saat ini meningkat penggunaannya yang marak beredar saat ini adalah jenis obat zenith. Dimana menurutnya peredaran obat zenith ini sangat sulit dibendung penggunaannya apabila hanya menggunakan UU Kesehatan Nomor 36 Tahun 2009. Karena hukuman yang ringan bagi pelanggarnya yang tidak dapat memberikan efek jera bagi penggunanya. Sehingga diharapkan dengan adanya Perda khusus di Kota Banjarmasin yang mengatur tentang P4GN tersebut akan dapat memberikan sanksi yang lebih tegas dan keras lagi. Agar dari kepolisian dan BNN dalam memberantasnya bias lebih tegas.". 3

Berdasarkan hal tersebut kemudian DPRD Kota Banjarmasin membuat Raperda mengenai narkotika tersebut dan saat ini DPRD Kota Banjarmasin akan memparipurnakan Perda narkoba dan zat adiktif tersebut. Selain itu latarbelakang dibuatnya Raperda tersebut karena sangat mengkwatirkannya peredaran obat-obatan terlarang jenis carnophen atau pil zenith di Kota Banjarmasin yang sudah masuk kelingkungan sekolah. Badan Narkotika Nasional Kota Banjarmasin dalam kegiatan sosialisasibahaya penyalahgunaan narkoba di masyarakat, khususnya di sekolah sekolah menggunakan metode komunikasi persuasif yang diungkapkan oleh para ahli seperti Browmen, Newcomb, serta Cartwright salah satunya yaitu metode partisipasi yang mengikutsertakan seseorang atau publik pada kegiatan agar timbul saling pengertian diantara mereka.

Awalnya pil jenis zenith termasuk dalam Undang-Undang baru ke dalam golongan 1 narkotika, sehingga terdapat sanksi bagi pemakai dan pengedarnya. Raperda tersebut juga lebih fokus pada pembinaan bagi penyalahgunaannya, terutama bagi penggunanya yang masih dibawah umur.

Berdasarkan masalah diatas maka peneliti tertarik untuk meniliti tentang “ Implementasi Peraturan Daerah Nomor 16 Tahun 2012 Tentang Pencegahan Dan Penanggulangan Terhadap Penyalahgunaan Dan Peredaran Gelap Narkotika, Psikotropika Dan Zat Adiktif Lainnya di Kota Banjarmasin (Studi Kasus Pencegahan Narkoba Oleh Badan Narkotika Nasional) ".

\section{Fokus Penelitian}

Fokus penelitian digunakan dengan menggunakan teori implementasi kebijakan

\footnotetext{
${ }^{3}$ Antarakalsel.com,Sabtu8April2017.
} 
menurut George C. Edward III. Dengan alasan ingin mengetahui dan menganalisis bagaimana faktor yang terdapat pada Implementasi Peraturan Daerah Nomor 16 Tahun 2012 Tentang Pencegahan Dan Penanggulangan Terhadap Penyalahgunaan Dan Peredaran Gelap Narkotika, Psikotropika Dan Zat Adiktif Lainnya (P4GN) di Kota Banjarmasin (Studi Kasus Pencegahan Narkoba Oleh Badan Narkotika Nasional). Dimana menurut George C. Edward III dalam Agustino, (2014:150) terdapat 4 faktor yang mempengaruhi implementasi kebijakan, yaitu :

a. Komunikasi

1. Transmisi: penyalur komunikasi yang baik.

2. Kejelasan: pelaksana kebijakan menerima komunikasi tidak boleh membingungkan.

3. Konsistensi: perintah yang diberikan, harus jelas dan tidak berubah saat dilaksanakan.

4. Transmisi: penyalur komunikasi yang baik.

5. Kejelasan: pelaksana kebijakan menerima komunikasi tidak boleh membingungkan.

6. Konsistensi: perintah yang diberikan, harus jelas dan tidak berubah saat dilaksanakan.

b. Sumberdaya

1. Staf: staff yang tidak mencukupi, memadai dan tidak kompoten dibidangnya.

2. Informasi: pertama berhubungan dengan cara melaksanakan kebijakan. Kedua mengenai data kepatuhan pelaksana kebijakan terhadap peraturan yang ditetapkan.

3. Wewenang: kewenangan harus memiliki sifat formal agar dapatdilaksanakan.

4. Fasilitas: berupa fasilitas fisik (sarana dan prasarana).

c. Disposisi

1. Pengangkatan birokrat: personil pelaksanaan kebijakan orang yang memiliki dedikasi terhadap kebijakan yang telah dibuat.

2. Insentif: digunakan pada kecenderungan pelaksana dengan memanipulasi insentif.

d. Struktur Birokrasi

Ada dua cara, yaitu Standar Operating Prosedures (SOPS) diartikan usaha dilakukan secara terus menerus yang membuat para karyawan melaksanakan tugasnya setiap hari. Sedangkan fragmentasi adalah usaha dilakukan berupa penyebaran tanggungjawab kegiatan berbagai karyawan dilakukan di semua unit kerjanya

Rumusan Masalah
Rumusan masalah dalam penelitian ini, yaitu bagaimana faktor komunikasi, sumberdaya, disposisi dan struktur birokrasi pada implementasi peraturan daerah nomor 16 tahun 2012 tentang pencegahan dan penanggulangan terhadap penyalahgunaan dan peredaran gelap narkotika, psikotropika dan zat adiktif lainnya (P4GN) di Kota Banjarmasin (studi kasus pencegahan narkoba oleh badan narkotika nasional)?

Adapun tujuan penulisannya yaitu untuk mengetahui dan menganalisis faktor komunikasi, sumberdaya, disposisi dan struktur birokrasi pada implementasi peraturan daerah nomor 16 tahun 2012 tentang pencegahan dan penanggulangan terhadap penyalahgunaan dan peredaran gelap narkotika, psikotropika dan zat adiktif lainnya (P4GN) di Kota Banjarmasin (studi kasus pencegahan narkoba oleh badan narkotika nasional).

\section{Kegunaan Penelitian}

- Agar dapat menambahkan beberapa teori atau konsep dalam ilmu lainnya.

- Dapat memberikan masukkan atau kontribusi berupa hasil kajian yang dapat dijadikan panduan bagi pemerintah.

\section{TINJAUAN TEORITIS Kebijakan Publik}

William N. Dunn, 1994 (Pasalong, 2017:47) kebijakan publik adalah rangkain pilihan saling berkaitan yang dibuat oleh lembaga atau pejabat pemerintah pada bidang berkaitan dengan tugas pemerintahan, yaitu pertahanan, keamanan, energi, kesehatan, pendidikan, kesejahteraan masyarakat, kriminalitas, perkoataan dan lainnya.

Menurut Nugroho, 2006 (Pasalong, 2017:48) terdapat 3 jenis kebijakan publik:

a. Kebijakan bersifat makro: kebijakan atau peraturan yang bersifat umum.

b. Kebijakan bersifat meso: kebijakan memiliki sifat menengah/memperjelas pelaksanaan.

c. Kebijakan bersifat mikro: kebijakan yang memiliki sifat mengatur pelaksanaan.

Selanjutnya Dunn, 2003 (Nawawi, 2009:11) terdapat beberapa model kebijakan:

a. Model deskripsi: model yang dapat dibandingkan dan dikontraskan dari berbagai dimensi.

b. Model Normatif: dapat membantu menentukan tingkat kapasitas pelayanan yang optimum, pengaturan volume waktu yang optimum.

c. Model verbal: digunakan secara komunikatif, bukan logika simbolis dan matematika.

d. Model simbolis: menerangkan hubungan diantara variabel kunci yang dipercaya.

e. Model procedural: menampilkan hubungan dinamis antara variabel yang diyakini menjadi ciri suatu masalah kebijakan publik.

Komunikasi Persuasif 
Komunikasi merupakan proses penyampaian pikiran, gagasan, dan ide kepada orang lain dengan harapan mendapat reaksi yang sesuai dengan yang diinginkan. (Suselo, 2007: 26). Sedangkan persuasi adalah kegiatan yang bertujuan untuk mengubah sikap, pendapat, atau perilaku, yang dilakukansecara halus, luwes dan mengandung sifat-sifat manusiawi (Effendy, 1998:27). Maka dari itu Hogan (dalam Taillard, 2005: 145) menyatakan bahwa komunikasi persuasif merupakan kemampuan untuk mempengaruhi perilaku orang lain atau kelompok orang atau kemampuan untuk memberikan induksi keyakinan dan nilai-nilai ke dalam diri orang lain dengan mempengaruhi pemikiran dan tindakan mereka melalui strategi yang spesifik.

Terdapat beberapa metode persuasi yang diungkapkan oleh beberapa ahli seperti Browmen, Newcomb, Cartwright, dan lain lain, yaitu:

1 Metode Partisipasi: Mengikutsertakan seseorang atau public pada

suatu kegiatan agar timbul saling pengertian diantara mereka.

2 Metode Asosiasi: Penyajian pesan yang dihubungkan dengan suatu peristiwa yang menarik perhatian publik.

3. Icing Device: Menyajikan suatu pesan dengan menggunakan pendekatan emosi agar lebih menarik, dapat memberikan kesan yang tidak mudah dilupakan serta lebih menonjol daripada yang lain.

4. Pay-off idea: Penyajian pesan yang mengandung anjuran, Diana apabila anjuran itu ditaati, pasti hasilnya memuaskan

5. Fear arousing: Menyajikan pesan yang menimbulkan rasa khawatir atau takut apabila tidak mematuhi informasi-informasi yang di sajikan tersebut.

\section{Implementasi Kebijakan}

Van Meter dan Van Horn, 1975 (Nawawi, 2017:131) implementasi kebijakan adalah tindakan dilakukan baik oleh individu, pejabat dan kelompok pemerintah atau swasta yang diarahkan untuk mencapai tujuan yang ingin digariskan dalam keputusan kebijakan.

Menurut D. L. Weimer dan Aidan R. Vining, 1999 (Pasalong, 2017:69) ada beberapa hambatan dalam implementasi:

a. Logika yang digunakan oleh suatu kebijakan.

b. Hakekat kerjasama yang dibutuhkan.

c. Ketersediaan sumberdaya manusia yang memiliki kemampuan dan komitmen.

Terdapat beberapa faktor yang mempengaruhi implementasi kebijakan:

a. Teori George C. Edwards III (1980): toeri ini dinamakan "Direct and Indirect Impact On Implementation" implementasi terdiri dari 4 faktor, yaitu komunikasi, sumber daya, disposisi dan struktur birokrasi.

b. Teori Merilee S. Grindle (1980): mengatakan bahwa terdapat 2 variabel yang berpengaruh dalam implementasi kebijakan, yaitu Isi Kebijakan (content of policy) dan Lingkungan Kebijakan(context of implementation).

c. Teori Donald S. Van Meter dan Carl E. Van Horn (1975): mengatakan bahwa ada 6 variabel yang mempengaruhi implementasi, yaitu standar dan sasaran kebijakan, sumberdaya, hubungan antar organisasi, karakteristik agen pelaksana, kondisi, sosial, politik dan ekonomi dan disposisi implementor.

d. Teori David L Weimer dan Aidan R. Vining (1999): mengatakan terdapat 3 kelompok variabel besar yang dapat mempengaruhi implementasi kebijakan, yaitu logika kebijakan, lingkungan tempat kebijakan dioperasikan dan kemampuan implementor kebijakan.

Narkotika dan Obat-Obatan Terlarang

Terdapat 3 jenis golongan narkoba:

a. Narkotika golongan I: Pada pasal 6 UU Narkotika (Ratna WP, 2017:44), narkotika yang biasa digunakan dengan tujuan pengembangan ilmu pengetahuan dan tidak digunakan dalam terapi yang dapat mengakibatkan ketergantungan.

b. Narkotika golongan II: berkhasiat dalam pengobatan digunakan sebagai pilihan terakhir terapi dan pengembangan ilmu pengetahuan, ketergantungan.

c. Narkotika golongan III: berkhasiat dalam pengobatan, digunakan terapi untuk tujuan pengembangan ilmu pengetahuan dan potensi ringan menyebabkan ketergantungan.

Jenis narkotika dalam kehidupan sehari-hari, yaitu: candu/opium, morphine, heroin, cocaine, ganja dan narkotika sintesis atau buatan (depressants, stimulants, hallucinogens/halusinasi dan Obat adiktif lain).

Sedangkan Bahaya dan akibat dari narkotika dapat bersifat bahaya pribadi bagi si pemakai narkotika dan dapat berbahaya secara sosial. Adapun gejalanya, yaitu:

a. Euphoria dalam Makaro dkk, 2005:49 diartikan sebagai rangsangan berupa kegembiraan yang tidak sesuai dengan kenyataan dan kondisi yang diperoleh oleh badan si pemakai.

b. Delirium, dalam Makaro dkk, 2005:49 adalah suatu keadaan dimana si pengguna narkotika 
mengalami penurunan kesadaran dan menimbulkan kegelisahan.

c. Halusinasi, dalam Makaro dkk, 2005:50 diartikan suatu keadaan dimana si pemakai narkotika mengalami khayalan, seperti melihat dan mendengar yang tidak.

d. Weakness, dalam Makaro dkk, 2005:50 adalah kelemahan yang dialami fisik.

e. Drowsiness, dalam Makaro dkk, 2005:50 adalah tingkat kesadaran yang merosot.

f. Coma, dalam Makaro dkk, 2005:50 mengakibatkan puncak kemerosotan dan kematian.

\section{Kebijakan dan Implementasi P4GN}

P4GN adalah rumusan kebijakan nasional

Badan Narkotika Nasioanal di bidang pencegahan dan pemberantasan, penyalahgunaan dan peredaran gelap Narkotika, Psikotropika dan Prekurser dan alkohol. Kebijakan P4GN berawal dari konvensi dilakukan oleh Perserikatan Bangsa-Bangsa (PBB) tahun 1961. Di Kalimantan Selatan dalam melaksanakan P4GN pemerintah mengeluarkan Perda Kalsel Nomor 16 tahun 2012 Tentang Pencegahan dan Penanggulangan Terhadap Penyalahgunaan dan Peredaran Gelap Narkotika, Psikotropika dan Zat Adiktif Lainnya. Perda ini digunakan oleh semua Kota atau Kabupaten yang ada di Kalsel, termasuk Kota Banjarmasin. Di Banjarmasin yang memiliki kewenangan melaksanakan perda ini Badan Narkotika Nasional (BNN) Kota Banjarmasin.

Asas pencegahan dan penanggulangan terhadap penyalahgunaan dan peredaran gelap narkotika, psikotropika dan zat adiktif lainnya di Kalsel adalah keagamaan, keadilan, pengayoman, kemanusiaan, ketertiban, perlindungan, keamanan, nilai-nilai ilmiah, kepastian hukum, kemitraan dan kearifan lokal. Pencegahan adalah semua upaya yang ditujukan untuk menghindarkan masyarakat dari penyalahgunaan dan peredaran gelap narkotika, psikotropika dan zat adiktif lainnya sedangkan penanggulangan adalah semua upaya yang ditujukan untuk menekan penyalahgunaan dan peredaran galap narkotika, psikotropika dan zat adiktif lainnya di masyarakat melalui rehabilitasi serta pembinaan dan pengawasan.

\section{METODE PENELITIAN}

Pada penelitian ini menggunakan pendekatan peneletian kualitatif dengan jenis tipe penelitian deskriptif. Lokasi penelitian ini dilakukan di Badan Narkotika Nasional (BNN) Kota Banjarmasin karena di Banjarmasin rawan penyebaran dan penggunaan narkoba terutama narkoba jenis zenith.

Adapun teknik analisis data yang digunakan dalam penelitian ini adalah teknik analisis data menurut Miles dan Huberman, 1984 (Sugiyono, 2018:246) analisis data ini ada tiga macam yaitu data reduction, data display dan conclusion drawing/verification. Sedangkan keabsahan data yang dipilih dalam penelitian ini yaitu dengan cara uji kredibilitas untuk menguji kebenarannya dengan beberapa sumber yang berkaitan.

\section{GAMBARAN UMUM}

BNN Kota Banjarmasin merupakan perwakilan BNN yang berlokasi di Jl. Pangeran Hidayatullah Kelurahan Banua Anyar Kecamatan Banjarmasin Utara Kota Banjarmasin Kalimantan Selatan.

BNNK Banjarmasin dipimpin oleh Kepala BNN Kota Banjarmasin yang bertanggungjawab kepada Kepala BNN Provinsi. BNNK Banjarmasin terdiri dari:
a. Kepala
(H.Syamsudin,SE)
BNNK
Banjarmasin

Berperan sebagai pemimpin yang memimpin pelaksanaan tugas, fungsi, dan wewenang BNN dalam wilayah Kota Banjarmasin.

b. Kepala Sub Bagian Umum (Rusianti, S.AP) Berperan melakukan penyiapan pelaksanaan penyusunan rencana program dan anggaran, urusan tata persuratan, rumah tangga, kepegawaian, keuangan, kearsipan, dokumentasi, hubungan masyarakat, bantuan hukum dan kerja sama, evaluasi, dan penyusunan laporan BNN Kota Banjarmasin.

c. Kepala Seksi Pencegahan dan Pemberdayaan Masyarakat (Hj. Siti Salamah, SKM., MM) Berperan melakukan penyiapan pelaksanaan kebijakan teknis P4GN di Bidang Pencegahan dan Pemberdayaan Masyarakat dalam wilayah Kota Banjarmasin.

d. Kepala Seksi Rehabilitasi (Hj. Nurjaidah, MM)

Berperan untuk melakukan penyiapan pelaksanaan kebijakan teknis P4GN di Bidang Rahabilitasi dalam wilayah Kota Banjarmasin.

e. Kepala Seksi Pemberantasan (H.Syamsudin, SE)

Berperan melakukan penyiapan pelaksanaan kebijakan teknis P4GN di Bidang Pemberantasan dalam rangka pemetaan jaringan kejahatan terorganisasi penyalahgunaan dan peredaran gelap narkotika, psikotropika, prekursor, dan bahan adiktif lainnya kecuali bahan adiktif untuk tembakau dan alkohol dalam wilayah Kota Banjarmasin.

Tabel dibawah ini menunjukkan data rehabilitasi Badan Narkotika Nasional Kota Banjarmasin berdasarkan bulan Tahun 2018: 
MUTAKALLIMIN; Jurnal Ilmu Komunikasi

Vol 3 No 2 November 2020

\begin{tabular}{|c|c|c|c|c|}
\hline \multirow[t]{2}{*}{ No } & No & Bulan & $\begin{array}{c}\text { Banyaknya } \\
\text { (Jiwa) }\end{array}$ & \multirow{2}{*}{$\begin{array}{l}\text { aknya } \\
\text { a+Anak } \\
\text { iwa) }\end{array}$} \\
\hline & 1. & Januari & 4 & \\
\hline 1. & 2. & Februari & 7 & 4 \\
\hline 2. & 3. & Maret & 8 & 7 \\
\hline 3. & 4. & April & 7 & 8 \\
\hline 4. & 5. & Mei & 0 & 7 \\
\hline 5. & 6. & Juni & 1 & 0 \\
\hline 6. & 7. & Juli & 8 & 1 \\
\hline 7. & 8. & Agustus & 8 & 8 \\
\hline 8. & 9. & September & 3 & 8 \\
\hline 9. & 10. & Oktober & 7 & 3 \\
\hline 10. & 11. & November & 14 & 7 \\
\hline 11. & 12. & Desember & $\frac{17}{51}$ & 14 \\
\hline 12. & & Jumlah & 118 & 51 \\
\hline & Jum & & & 18 \\
\hline
\end{tabular}

\section{HASIL dan PEMBAHASAN}

a. Komunikasi

1. Transmisi

Pada hasil wawancara indikator transmisi yang terdapat pada faktor komunikasi menurut teori implementasi kebijakan Edward III dapat dikatakan belum terlaksana dengan baik. Berdasarkan pendapat pelaksana kebijakan yang ada di BNN Kota Banjarmasin sudah memiliki pengetahuan yang cukup mengenai P4GN secara singkat. Tetapi hal berbeda diungkapkan oleh masyarakat. Masih ada masyarakat yang tidak mendapatkan sosialisasi secara langsung oleh BNN Kota Banjarmasin sehingga tidak mengetahui secara jelas tentang P4GN. Seperti yang diungkapkan oleh Siti Zaenab dan Maimunah. Selain tidak mendapatkan sosialisasi Siti Zaenab juga tidak pernah mendapatkan informasi melalui media lainnya.

Sedangkan Ahmad Aminullah juga tidak

Rehabilitasi BNN Kota Banjarmasin berdasarkan bulan

Tabel dibawah ini menunjukkan data rehabilitasi Badan Narkotika Nasional Kota Banjarmasin berdasarkan Kecamatan pada Tahun 2018:

\begin{tabular}{|c|c|c|c|c|c|c|c|c|}
\hline \multirow[b]{2}{*}{ No } & \multirow[b]{2}{*}{ Bln } & \multicolumn{6}{|c|}{ Kecamatan } & \multirow{2}{*}{$\begin{array}{l}\text { Jum } \\
\text { (Bln) }\end{array}$} \\
\hline & & Utr & Sltan & Teng & Bart & Tim & $\begin{array}{c}\text { Luar } \\
\text { Kot }\end{array}$ & \\
\hline 1. & $\operatorname{Jan}$ & - & 3 & - & - & & 1 & 4 \\
\hline 2. & Feb & - & 1 & - & 1 & 2 & 1 & 7 \\
\hline 3. & Mar & 1 & 2 & - & - & 3 & 2 & 8 \\
\hline 4. & Apr & 2 & 1 & - & - & 3 & 1 & 7 \\
\hline 5. & Mei & - & - & - & - & - & - & 0 \\
\hline 6. & Juni & - & - & - & - & 1 & - & 1 \\
\hline 7. & Juli & 2 & - & - & 1 & 5 & - & 8 \\
\hline 8. & Agus & 3 & 2 & 1 & - & 2 & - & 8 \\
\hline 9. & Sept & 1 & 1 & 1 & - & - & - & 3 \\
\hline 10. & Oltt & 1 & - & 3 & - & 3 & - & 7 \\
\hline 11. & Nov & 2 & 8 & - & - & 2 & 2 & 14 \\
\hline 12. & $\overline{\text { Des }}$ & 4 & 8 & 2 & 5 & 4 & 28 & 51 \\
\hline & Jum & 16 & 26 & 7 & 7 & 27 & 35 & 118 \\
\hline
\end{tabular}

Tabel 2

Rehabilitasi BNN Kota Banjarmasin berdasarkan kecamatan

Pada tabel dibawah ini menunjukkan data rehabilitasi Badan Narkotika Nasional Kota Banjarmasin berdasarkan umur pada Tahun 2018, yaitu:

Tabel 3

Rehabilitasi BNN Kota Banjarmasin berdasarkan umur

pernah mendapatkan sosialisasi khusus mengenai P4GN dan hanya pernah mendapatkan informasi mengenai penyalahgunaan narkoba saja tidak spesifik seperti perda P4GN. Sedangkan menurut pemaparan Evita dan Suryati mereka pernah mendapatkan sosialisasi. Tetapi Evita sudah lama mendapatkan sosialisasi tersebut yaitu pada 2 tahun yang lalu dan Evita juga mengungkapkan bahwa tidak pernah mendapatkan informasi lainnya selain sosialisasi 2 tahun yang lalu yang di adakan di kampusnya.

2. Kejelasan

Komunikasi yang diterima tentunya haruslah jelas, baik pengetahuan mengenai dasar hukum pelaksanaan kebijakan tersebut. Dalam kebijakan P4GN ini ketiga pelaksana kebijakan yang ada di BNN Kota Banjarmasin mengatakan bahwa dasar hukumnya adalah UU No.35 Tahun 2009. Dimana menurut Kasubbag Umum BNN Kota Banjarmasin didalam UU ada yang mengatur mengenai kebijakan P4GN.

Tetapi berbanding terbalik dengan pelaksana kebijakan lainnya. Masyarakat yang ada di Kota Banjarmasin tidak ada yang mengetahui dasar hukum dari pelaksana kebijakan P4GN. Seperti yang diungkapkan oleh Maimunah yang mengatakan tidak mengetahui dasar hukumnya karena tidak pernah mendapatkan sosialisasinya. Hal yang sama juga diungkapkan Ahmad Aminullah yang mengatakan tidak mengetahui dasar hukumnya karena menurutnya kurangnya sosialisasi dan pihak terkait kurang memanfaatkan sosial media sebagai media untuk bersosialisasi terhadap kebijakan yang 
dibuat. Sehingga disimpulkan indikator kejelasan pada faktor komunikasi menurut teori implementasi kebijakan Edward III belum terlaksana secara maksimal. Sehinnga indikator ini masih belum dapat dilaksanakan secara maksimal.

\section{Konsistensi}

Berdasarkan hasil wawancara indikator konsistensi yang terdapat dalam faktor komunikasi sudah terlaksana dengan baik. Karena pendapat ketiga pelaksana kebijakan yang terdapat di BNN Kota Banjarmasin, semua yang tertuang di dalam dasar hukum mengenai P4GN sudah berjalan konsisten.

Seperti yang diungkapkan oleh Kassubag Umum BNN Kota Banjarmasin yang mengatakan bahwa sudah berjalan secara konsisten. Contohnya saat pelaksanaan P4GN staffnya sudah kompoten dan sudah didasari dengan ilmu mengenai penyuluhan.

Hal tersebut juga sudah sesuai dengan pendapat Edward III karena indikator konsistensi menurut Edward III dapat diartikan sebagai suatu perintah yang diberikan dalam pelaksanaan suatu komunikasi. Dimana perintah tersebut haruslah konsisten dan jelas (untuk ditetapkan atau dijalankan).

b. Sumberdaya

\section{Staf}

Pada hasil wawancara dapat disimpulkan bahwa indikator staff masih belum berhasil dijalankan secara maksimal. Hal ini sesuai dengan informasi yang diperoleh dari pelaksana kebijakan yang terdapat di BNN Kota Banjarmasin. Dimana diantara ketiga pelaksana kebijakan, ada dua orang pelaksana kebijakan yang mengatakan staff yang terdapat di BNN Kota Banjarmasin belum memadai. Hal ini diungkapkan oleh Kassubag Umum dan Kasi Pencegahan dan Pemberdayaan Masyarakat yang sepakat mengatakan bahwa jumlah staff yang ada di BNN Kota Banjarmasin belum memadai jumlahnya karena kurangnya sumber daya manusia.

Tetapi staff yang terdapat di BNN Kota Banjarmasin sudah kompoten dibidangnya masing-masing seperti yang diungkapkan Kasi Pencegahan dan Pemberdayaa Masyarakat. Staffnya sudah kompoten dibidangnya karena mampu memberikan akses komunikasi, informasi dan edukasi kepada masyarakat tentang P4GN. Sedangkan menurut masyarakat. Masyarakat tidak ada yang mengetahui apakah staff yang ada di BNN Kota Banjarmasin sudah memadai dan kompoten atau tidaknya. Karena mereka tidak pernah mendapatkan informasi dan melihat secara langsung staff yang ada di BNN Kota Banjarmasin.

Tetapi ada dua masyarakat yaitu Ahmad Aminullah yang mengatakan bahwa menurutnya staff yang ada di BNN Kota Banjarmasin juga belum memadai jumlah staffnya karena masih kurangnya pengetahuan masyarakat terhadap Perda tersebut dan staffnya juga masih belum kompoten dibidangnya karena masih maraknya penggunaan narkoba di Kota Banjarmasin. Masyarakat yang bernama Denny juga mengungkan hal yang sama. Menurut Denny staff yang ada di BNN Kota Banjarmasin saat ini jumlah staffnya belum memadai karena informan tersebut belum pernah mendapatkan sosialisasi dan menurutnya staffnya kurang kompoten karena masih belum melaksanakan sosialisasi secara maksimal.

2. Informasi

Pada indikator informasi menurut Edward III sudah berhasil dilaksanakan dengan baik. Dimana ketiga pelaksana kebijakan di BNN Kota Banjarmasin sudah mengetahui masing-masing tugasnya dan telah melaksanakan tugasnya sesuai dengan peraturan yang ada di dalam dasar hukum kebijakan P4GN.

Salah satunya seperti yang diungkapkan oleh Kasubbag umum yang mengatakan bahwa sudah mengetahui tugasnya yaitu mengadakan sosialisasi/penyuluhan tentang P4GN dan sudah sesuai dengan peraturan P4GN seperti memberikan sosialisasi/penyuluhan dan tes urine. Biasanya sosialisasi/penyuluhan dan tes urine dilaksanakan seperti di lingkungan sekolah, instansi pemerintah, SPBU dan dimana-mana saja atau tidak menentu.

3. Wewenang

Berdasarkan pendapat pelaksana kebijakan P4GN di BNN Kota Banjarmasin, mereka sebagai pelaksana kebijakan sudah melaksanakan tugasnya sesuai dengan kewenangan yang terdapat di peraturan P4GN. Hal ini sesuai dengan pendapat salah satu pelaksana kebijakannya, yaitu Kasi Pencegahan dan Pemberdayaan Masyarakat yang mengatakan bahwa sudah melaksanakan sesuai dengan kewenangan yang ada karena telah terlaksananya upaya pencegahan dan penanggulan P4GN kepada masyarakat, lingkungan pendidikan dan instansi pemerintah/swasta. Jadi, dapat dikatakan 
indikator wewenang sudah berhasil dilaksanakan.

4. Fasilitas

Indikator terakhir dalam faktor sumberdaya menurut Edward III adalah fasilitas. Fasilitas di BNN Kota Banjarmasin dalam melakanakan kebijakan P4GN dapat dikatakan sudah berhasil dilaksakan. Ini sesuai dengan ketiga pendapat pelaksana kebijakan P4GN yang ada di BNN Kota Banjarmasin. Hal ini sesuai dengan pendapat pelaksana kebijakan yaitu Kassubag Umum yang mengatakan bahwa fasilitasnya tentunya ada seperti gedung, komputer, layar+led dan klinik untuk memeriksa urin.

Kalau prasarananya juga ada seperti mobil dinas khusus untuk memberikan sosialisasi dan tes urine yang dilengkapi dengan toilet di dalam mobil (mobil unit pemberdayaan masyarakat). Sedangkan pendapat masyarakat mereka tidak mengetahui fasilitas yang ada di BNN Kota Banjarmasin. Tetapi menurut masyarakat tentunya terdapat sarana dan prasarana di BNN Kota Banjarmasin untuk mendukung dalam pelaksanaan kebijakan yang telah dibuat. Sehingga dapat dikatakan indikator ini sudah berhasil dilaksanakan dengan baik.

Dibawah ini adalah salah satu fasilitas terdapat di Badan Narkotika Nasional Kota Banjarmasin yaitu klinik bagi pecandu yang berobat.
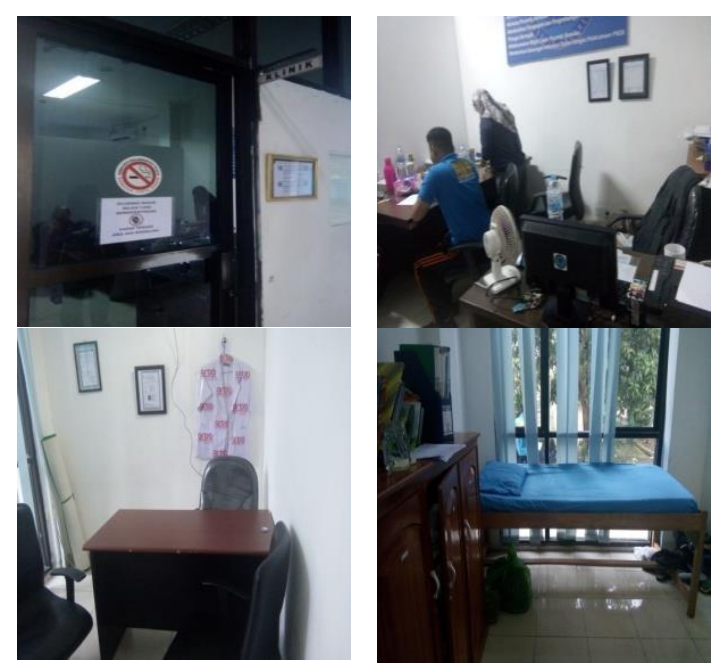

Gambar 1

Klinik Badan Narkotika Nasional Kota Banjarmasin

c. Disposisi

1. Pengangkatan birokrat
Hasil wawancara menunjukkan bahwa semua pelaksana kebijakan yang terdapat di BNN Kota Banjarmasin sudah mempunyai dedikasi/bertanggung yang tinggi dan disiplin dalam melaksanakan kebijakan P4GN di Kota Banjarmasin. Hal ini sesuai yang diungkapkan oleh ketiga pelaksana kebijakan yang ada di BNN Kota Banjarmasin. Seperti yang diungkapkan oleh Plt. Kasi Rehabilitasi yang mengatakan sudah disiplin dan bertanggungjawab. Contohnya pelaksana kebijakan yang terdapat di Kasi Rehabilitasi kalau terdapat pecandu yang datang untuk berobat langsung dilayani dengan baik.

Sehingga dapat disimpulkan bahwa indikator pengangkatan birokrat yang terdapat dalam faktor disposisi atau sikap pelaksana menurut teori implementasi kebijakan Edward III sudah dijalankan secara maksimal.

2. Insentif

Pada hasil wawancara diatas dapat dikatakan bahwa indikator insentif yang terdapat dalam faktor disposisi atau sikap pelaksana menurut teori implementasi kebijakan Edward III belum dijalankan secara maksimal. Karena dari ketiga pelaksana kebijakan yang ada di Kota Banjarmasin ada salah satu pelaksana kebijakan memiliki pendapat yang berbeda dengan pelaksana kebijakan lainnya.

Seperti yang diungkapkan Plt. Kasi Rehabilitasi yang mengatakan bahwa tidak terdapat insentif. Sedangkan Kassubag Umum dan Kasi Pencegahan dan Pemberdayaan Masyarakat mengatakan bahwa ada insentif yang diterima. Seperti yang diungkapkan Kassubag Umum yang mengatakan bahwa insentif yang diberikan berupa uang yang diberikan kepada panitia seperti dana transportasi sesuai dengan ada yang di Dipa.

d. Struktur Birokrasi

1. Standar Operating Prosedures (SOPs)

Indikator Standar Operating Prosedures (SOPS) yang terdapat dalam faktor struktur birokrasi menurut teori implementasi kebijakan Edward III sudah berhasil dilaksanakan. Karena di setiap kegiatan sudah terdapat Standar Operating Prosedures (SOPs) dan semua kegiatan sudah dilaksanakan sesuai dengan Standar Operating Prosedures (SOPs) yang ada.

Seperti yang diungkapkan oleh Plt. Kasi Rehabilitasi yang mengatakan contohnya Standar Operating Prosedures (SOPs) dalam merujuk pasien dan Klinik. Sedangkan Kassubag Umum mengatakan contoh Standar Operating Prosedures (SOPs) yang ada seperti Standar Operating Prosedures (SOPs) untuk kegiatan pemerintah, swasta, masyarakat dan 
pendidikan. Berdasarkan hasil diatas maka dapat dilihat hal ini telah sesuai dengan teori implemetasi Edward III dan berhasil dilaksanakan dengan baik.

Berikut dapat dilihat SOP (Standar Operating Procedures) klinik terdapat di Badan Narkotika Nasional Kota Banjarmasin tahun 2019:
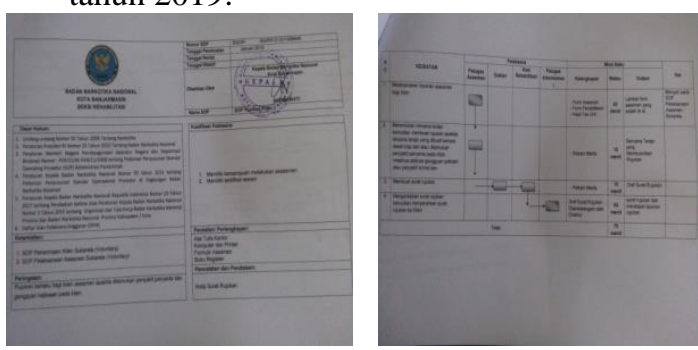

Gambar 2

SOP klinik
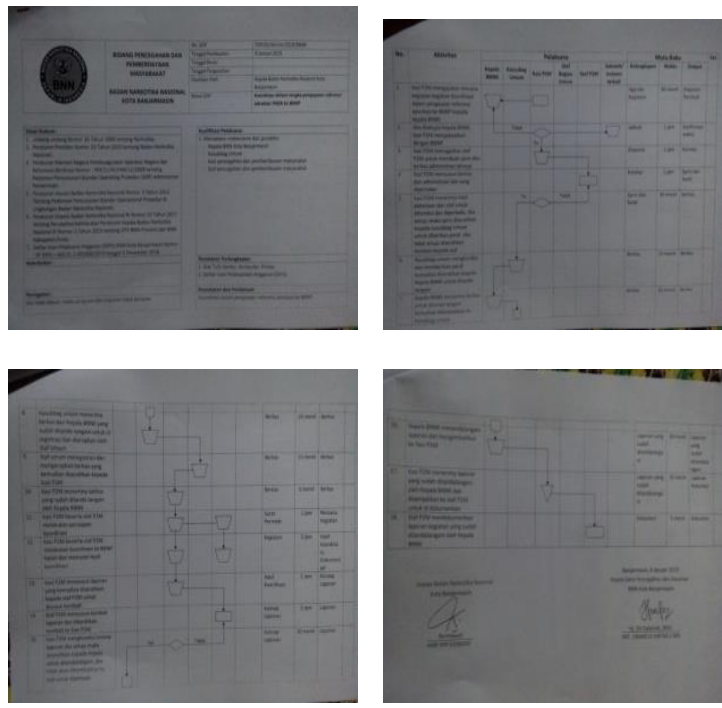

Gambar 3

SOP koordinasi dalam rangka pengayaan refrensi advokasi $P 4 G N$ ke BNNP
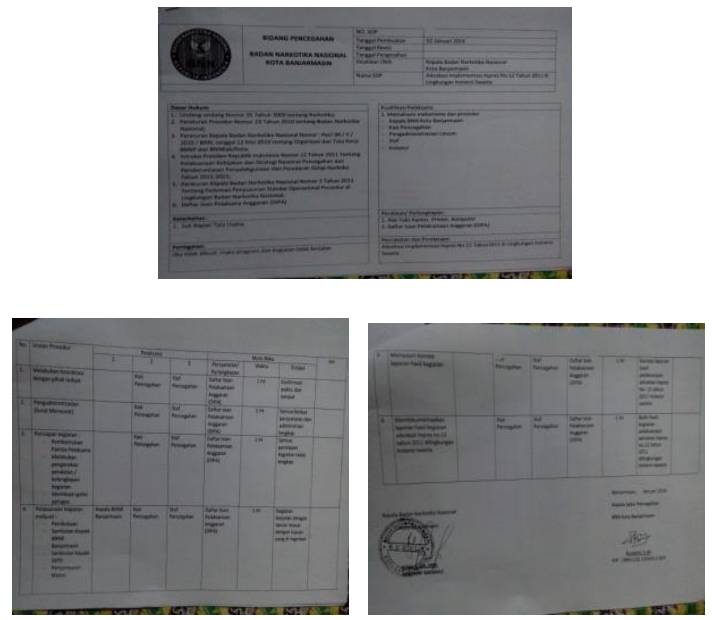

\section{Gambar 4}

SOP advokasi implementasi

Inpres No.12 Tahun 2011 di lingkungan instansi swasta

\section{2. fragmentasi}

Hasil wawancara menunjukkan bahwa indikator fragmentasi yang terdapat dalam faktor struktur birokrasi sudah dilaksanakan secara efektif. Hal ini sesuai dengan yang diungkapkan pelaksana kebijakan P4GN yang terdapat di BNN Kota Banjarmasin. Ketiga pelaksana kebijakan sepakat mengatakan bahwa Standar Operating Prosedures (SOPS) berlaku untuk semua masyarakat dan tidak ada hak istimewa bagi masyarakat tertentu.

Seperti diungkapkan oleh Kasi

Pencegahan dan Pemberdayaan yang mengatakan bahwa tidak ada hak istimewa yang diberikan karena semuanya dilaksanakan sesuai dengan hak dan kewajiban sebagaimana mestinya dan Plt. Kasi Rehabilitasi mengatakan bahwa semuanya berlaku untuk semua. Dimana semua pecandu yang ingin berobat di BNN Kota Banjarmasin semuanya dilayani secara gratis dan tidak ada hak istimewa yang diberikan kepada pecandu tertentu baik warga biasa atau dengan status apapun.

\section{PEMBAHASAN}

Komunikasi persuasif Badan Narkotika Nasional dalam Sosialisasi Bahaya Narkoba adalah cara Badan Narkotika Nasional dalam upaya pencegahan, pemberantasan, penyalahgunaan dan peredaran gelap narkoba (P4GN) di kalangan siswa sekolah menengah atas dan sederajat.

\section{Metode Partisipasi}

Berdasarkan pengamatan dan wawancara yang dilakukan, penulis menganalisa bahwa dari metode partisipasi maka yang menjadi permasalahan adalah Badan Narkotika Nasional terkadang kekurangan waktu yang menyebabkan inovasi seperti musikalisasi dan mini teater tidak disertakan dalam kegiatan sosialisasi dan anggota penggiat anti narkoba yang memiliki kesibukan masing-masing diluar kegiatan mereka bersama BNNK Banjarmasin sehingga dalam penerapan sosialisasinya, anggota BNNK hanya menggunakan slide powerpoint. Juga yang menjadi kendala adalah tidak adanya laporan pertanggungjawaban oleh teman teman penggiat, hal ini dikarenakan tidak adanya anggaran khusus untuk penggiat antinarkoba itu sendiri dan penggiat anti-narkoba ini juga bersifat non-organisasi yang berarti mereka tidak terikat oleh Badan Narkotika Nasional Kota Banjarmasin 


\section{Metode Asosiasi}

Metode Asosiasi adalah penyajian pesan yang dihubungkan dengan suatu peristiwa yang menarik perhatian publik. Biasanya pesan yang disajikan berupa kejadian kriminal seperti penjambretan, pembegalan dan pencurian barang berharga yang dilakukan oleh satu atau lebih pelaku, yang kemudian setelah diselidiki biasanya hasil kejahatan digunakan untuk membeli sabusabu dan narkoba jenis lainnya. Metode Asosiasi ini adalah metode umum yang sangat intens digunakan Badan Narkotika Nasional Kota Banjarmasin dalam menyampaikan sosialisasi bahaya penyalahgunaan narkoba, apalagi didukung oleh pemberitaan di media massa baik cetak maupun elektronik yang membuktikan bahwa kejadian atau cerita yang disampaikan adalah benar adanya dan tidak direkayasa, hingga dengan begitu memberikan pengetahuan bahwa bahaya narkoba ada disekitar kita dengan atau tanpa kita sadari.

Untuk itulah Badan Narkotika Nasional Kota Banjarmasin hadir untuk memberikan sosialisasi juga inovasi berupa pengaduan berbasis dalam jaringan (online) di jejaring sosial facebook agar masyarakat khususnya generasi penerus yaitu siswa sekolah agar lebih berhati- hati terhadap bahaya penyalahgunaan narkoba yang saat ini semakin mengkhawatirkan serta melaporkan setiap tindak kejahatan narkoba yang ada disekitar mereka.

\section{PENUTUP}

\section{Kesimpulan}

a. Faktor komunikasi, belum berhasil dilaksanakan secara maksimal karena diantara ketiga indikator implementasi kebijakan Edward III hanya satu indikator saja yang berhasil dilaksanakan yaitu konsistensi. Di indikator transmisi disebabkan ada masyarakat yang tidak mendapatkan sosialisasi secara langsung oleh BNN Kota Banjarmasin sehingga tidak mengetahui secara jelas tentang P4GN. Sedangkan indikator kejelasan penyebabnya tidak terlaksananya karena masyarakat yang ada di Kota Banjarmasin ada yang tidak mengetahui dasar hukum pelaksana kebijakan P4GN.

b. Faktor sumberdaya, belum berhasil karena diantara keempat indikatornya menurut teori implementasi kebijakan Edward III ada satu indikator yang belum dilaksanakan yaitu indikator staf. Penyebabnya karena sumber daya manusia yang terdapat di BNN Kota Banjarmasin masih kurang. Sedangkan indikator yaitu informasi, wewenang dan fasilitas sudah berhasil untuk dilaksanakan secara maksimal.

c. Faktor disposisi atau sikap pelaksana, belum berhasil dijalankan secara maksimal. Karena pada indikator insentif disebabkan menurut pengungkapan ketiga pelaksana kebijakan yang ada di BNN Kota Banjarmasin. Dua pelaksana kebijakan yaitu Kasubbag Umum dan Kasi Pencegahan dan Pemberdayaan Masyarakat mengatakan ada insentif yang diberikan kepada pegawai yang ada di BNN Kota Banjarmasin. Sedangkan menurut Plt. Kasi rehabilitasi mengatakan tidak insentif yang diberikan.

d. Faktor struktur birokrasi, sudah berhasil dijalankan secara maksimal. Karena indikator Standar Operating Prosedures (SOPs) dan fragmentasi sudah berhasil dijalankan secara maksimal. Di BNN Kota Banjarmasin sudah terdapat Standar Operating Prosedures (SOPs) untuk berbagai kegiatan dan sudah dilaksanakan serta tidak ada hak istimewa Saran yang diberikan kepada masyarakat tertentu.

a. Faktor komunikasi, Badan Narkotika Nasional Kota Banjarmasin lebih sering mengadakan sosialisasi tentang P4GN dilingkungan sekolah, kampus, pemerintahan dan swasta. Juga memberikan pengetahuan kepada masyarakat mengenai dasar hukumnya dan isi dari P4GN. Sosialisasi juga dapat dilakukan secara tidak langsung melalui sosial media. Agar anak muda dan masyarakat lebih mudah mendapatkan informasinya.

b. Faktor sumberdaya, dengan jumlah staff yang sudah cukup memadai dan kompoten. Fasilitas yang lengkap karena disetiap kasi sudah tersedia komputer, print dan alat penunjang lainnya. Serta terdapat mobil dinas khusus yang memiliki toilet untuk tes urine. Dengan lengkapnya hal seharusnya BNN Kota Banjarmasin dapat melaksanakan kebijakan dengan optimal. Sehingga semua masyarakat mendapatkan sosialisasi P4GN dan tidak hanya terfokus mengenai penyalahgunaan narkoba tetapi mengenai kebijakan P4GN secara keseluruhan. Misalnya mengadakan sosialisasi rutin melalui media sosial.

c. Faktor disposisi atau sikap pelaksana, sebaiknya pelaksana kebijakan melaksanakan tugasnya tidak mengharapkan insentif dan masyarakat tidak memberikan insentif.

d. Faktor Struktur birokrasi, sebaiknya Standar Operating Prosedures (SOPs) yang ada di BNN Kota Banjarmasin secara transparan diketahui masyarakat. Seperti Standar Operating Prosedures (SOPs) berobat ke BNN Kota Banjarmasin dan memberitahu masyarakat yang ingin direhabilitasi gratis dan kerahasian data aman. Sehingga pengguna penyalahgunaan narkoba ingin berobat segera berobat dan tidak akan masuk penjara. 


\section{REFERENSI}

Buku :

---------. 2010. Buku P4GN Bidang Pemberdayaan Masyarakat.

Ali, Faried dan Alam Andi Syamsu. 2016. Studi Kebijakan Pemerintahan. Cetakan Kedua. Bandung : Refika Aditama.

Agustino, Leo. 2014. Dasar-Dasar Kebijakan Publik. Cetakan Kelima. Bandung : Alfabeta.

Ardianto, Elvinaro dan Komala, Lukiati dan Karlinah, Siti, 2014. Komunikasi Massa, Simbiosa Rekatama Media, Bandung.

DeVito, Joseph A., 2011. Komunikasi Antarmanusia, Karisma Publishing, Jakarta

Effendy, Onong, 2003. Ilmu, Teori dan Filsafat Komunikasi, Citra Aditya Bakti, Bandung

Effendy, Onong, 2008. Dinamika Komunikasi, Remaja Rosdakarya, Bandung

Herabudin. 2016. Studi Kebijakan Pemerintahan dari Filosofi ke Implementasi. Bandung : Pustaka Setia.

Miles, Huberman dan Saldana, 2014. Qualitative Data Analysis, A Methods Sourcebook, Alfabeta, Bandung

Moleong, Lexy J, 2013. Metode Penelitian Kualitatif (Edisi Revisi), Remaja

Rosdakarya, BandungMakaro, Taufik. Suhasril dan Zakky Moh. 2005. Tindak Pidana Narkoba. Cetakan Kedua. Bogor : Ghalia Indonesia.

Martono, Nanang. 2016. Metode Penelitian Sosial: Konsep-Konsep Kunci. Jakarta:Rajawali Pers.

Nawawi, Ismail. 2009. Public Policy : Analisis, Strategi Advokasi Teori dan Praktek. Surabaya : PMN.

Pasalong, Harbani. 2017. Teori Administrasi Publik. Cetakan Kedelapan. Bandung : Alfabeta.

Rachmat dan Gunawan Dadang. 2016. Pengantar Ilmu Pemerintahan. Bandung: Pustaka Setia.
Ratna, WP. 2017. Aspek Pidana: Penyalahgunaan Narkotika. Yogyakarta : Legality.

Subarsono, AG. 2015. Analisis Kebijakan Publik : Konsep, Teori dan Aplikasi. Cetakan Ke tujuh. Yogyakarta : Pustaka Pelajar.

Sugiono. 2018. Metode Penelitian Kuantitatif, Kualitatif, dan $R \& B$. Cetakan Kedua Puluh Tujuh. Bandung : Alfabeta.

Syafiie, Inu Kencana. 2013. Ilmu Pemerintahan Edisi Revisi Kedua. Cetakan Keempat. Bandung : CV. Mandar Maju.

Tarigan, Irwan, Jasa. 2017. Narkotika dan Penanggulangannya. Yogyakarta:Deepublish.

Tim Penyusun FISIP ULM. 2015. Pedoman Penulisan Tesis. Banjarmasin.

\section{Perundang-Undangan :}

Instruksi Presiden Nomor 12 Tahun 2011 Tentang Pelaksanaan Kebijakan dan Strategi Nasional Pencegahan dan Pemberantasan Penyalahgunaan dan Peredaran Gelap Narkotika (P4GN).

Undang-Undang Nomor 5 Tahun 2009 Tentang Psikotropika.

Undang-Undang Nomor 35 Tahun 2009 Tentang Narkotika.

Peraturan Daerah Kalimantan Selatan Nomor 16 Tahun 2012 Tentang Pencegahan dan Penanggulangan Terhadap Penyalahgunaan dan Peredaran Gelap Narkotika, Psikotropika dan Zat Adiktif Lainnya.

Peraturan Presiden Nomor 23 Tahun 2010 Tentang Badan Narkotika Nasional.

\section{Website dan Berita :}

Antarakalsel. Edisi Sabtu 28 Juli 2018.

Antarakalsel. Edisi Sabtu 8 April 2017.

Banjarmasinpost.co.id. diakses pada Rabu 12 Maret 2019.

Redkal.com. diakses pada Rabu 12 Maret 2019.

Tribunnews. Edisi Rabu 29 Maret 2017. 